\title{
A rare case of follicular lymphoma with transformation to diffuse large B-cell lymphoma and transdifferentiation to histiocytic sarcoma
}

\author{
Anwar Rjoop, Soumya Pandey, Rebecca A. Levy* \\ Department of Pathology, University of Arkansas for Medical Sciences, Little Rock, United States
}

Received: May 31, 2016

Accepted: July 13, 2016

Online Published: August 8, 2016

DOI: $10.5430 /$ crcp.v3n4p45

URL: http://dx.doi.org/10.5430/crcp.v3n4p45

\begin{abstract}
This is an interesting case of a 53-year-old Caucasian male with a history of recurrent follicular lymphoma (FL) treated with chemotherapy. After 12 years, he developed lymphadenopathy and had an axillary lymph node biopsy which showed transformation to Diffuse Large B-cell lymphoma (DLBCL) with background FL. The patient was treated with chemotherapy and his course was complicated by cellulitis/abscess formation of the right thigh. Computerized Tomography scan showed a large necrotic nodal conglomerate within the right inguinal region measuring $7.8 \mathrm{~cm} \times 5.1 \mathrm{~cm}$ and an excisional biopsy was performed. The lymph node architecture was effaced by sheets of large, atypical, pleomorphic cells with open/vesicular chromatin and scattered prominent nucleoli. Focal areas showed residual/recurrent FL, grade I-II. Immunohistochemical stains showed that the large neoplastic cells express CD4, CD68, CD163, BCL-6, lysozyme, CD45 and S-100. The morphologic and immunophenotypic findings are consistent with histiocytic sarcoma (HS). Fluorescence in-situ hybridization studies of the HS showed translocation $\mathrm{t}(14 ; 18)(\mathrm{q} 32 ; \mathrm{q} 21)$, a gene rearrangement involving 3q27(BCL6), and gain of 14q32(IgH). The patient's prior FL and DLBCL were shown to have the same translocation $\mathrm{t}(14 ; 18)(\mathrm{q} 32 ; \mathrm{q} 21)$. The molecular findings show a common cell lineage between all three diagnoses confirming that FL can transform into DLBCL and transdifferentiate into HS.
\end{abstract}

Key Words: Follicular lymphoma, Diffuse large B-cell lymphoma, Histiocytic sarcoma, Lineage transdifferentiation

\section{INTRODUCTION}

Tumors of histiocytes and dendritic cells are extremely rare and their classification is still controversial. ${ }^{[1,2]}$ In the 2008 World Health Organization classification, ${ }^{[1]}$ primary histiocytic sarcoma (HS) is defined as a tumor with morphologic and immunohistochemical features similar to those of mature histiocytes and usually lack clonal immunoglobulin and $\mathrm{T}$ cell receptor genes. However, the 2008 WHO classification no longer requires the absence of $\mathrm{B}$ or $\mathrm{T}$ cell gene rearrangements as sporadic histiocytic sarcomas have shown evidence of clonal IGH and/or IGK gene rearrangements. ${ }^{[3]}$ The clinical presentation of HS varies depending upon the organs involved. Most patients present with symptoms due to unifocal or multifocal extranodal disease, most commonly involving the intestinal tract, skin, and soft tissues. ${ }^{[1]}$ Histiocytic/dendritic sarcomas can occur de novo or secondary to another malignant tumor, for example some cases are associated with mature B cell lymphomas ${ }^{[4-6]}$ and acute lymphoblastic leukemia/lymphoma. ${ }^{[7,8]}$ Small case series have shown histiocytic and dendritic cell (H/DC) neoplasms which

\footnotetext{
* Correspondence: Rebecca A. Levy; Email: RALevy@uams.edu; Address: Department of Pathology, University of Arkansas for Medical Sciences, 4301 W, Markham St, Slot 517, Little Rock, AR 72205, United States.
} 
occur secondary, or rarely synchronously, with follicular lymphoma (FL) and chronic lymphocytic leukemia/small lymphocytic lymphoma. These studies have shown evidence of cross-lineage transdifferentiation of B-cells to histiocytic and dendritic cell sarcomas. ${ }^{[9-11]}$ Interestingly, sporadic H/DC sarcomas have also shown evidence of clonal immunoglobulin receptor gene rearrangements. ${ }^{[3]}$

\section{CASE REPORT}

\subsection{History}

A 53-year-old Caucasian male with a twelve year history of recurrent FL with disease in the left axillary and left inguinal nodes for which he was treated with rituxan/bendamustine. He presented to our hospital with newly developed lymphadenopathy and had a left axillary lymph node dissection which showed diffuse large B cell lymphoma (DLBCL). The patient was treated with two cycles of rituximab, ifosfamide, carboplatin, and etoposide (R-ICE); his course was complicated by cellulitis/abscess formation in the right thigh requiring incision and drainage. Two months after the diagnosis of DLBCL, the patient developed lymphadenopathy and started to drain straw colored fluid from his proximal thigh incision site.

\subsection{Investigation}

Computed tomography scan showed a large necrotic nodal conglomerate within the right inguinal region that measured $7.8 \mathrm{~cm} \times 5.1 \mathrm{~cm}$. Lymph node excisional biopsy was performed. The lymph node architecture is predominantly effaced by sheets of large, atypical cells. The atypical cells have open/vesicular chromatin and large, pleomorphic nuclei. These cells have single or multiple nuclei with dark chromatin and bizarre nuclear contours and prominent nucleoli. The large neoplastic cells have abundant eosinophilic cytoplasm. There is a background of neutrophils and fibrosis. There are focal areas with intact germinal centers, which have scattered large centroblasts, suggestive of residual/recurrent FL.

Flow cytometry was performed on the specimen and there was no evidence of a monotypic B-cell or abnormal T-cell population. Immunohistochemical stains were performed with appropriate positive and internal negative controls. PAX-5, MUM1, BCL-2, BCL-6 are focally positive in the small area of involvement by residual FL (see Figure 1). CD21 highlights expanded follicular dendritic cell mesh in the focal follicular areas, representing the area of involvement by FL. CD21 is disrupted/absent in the other areas of the neoplastic tissue. CD3 highlights background T-cells.

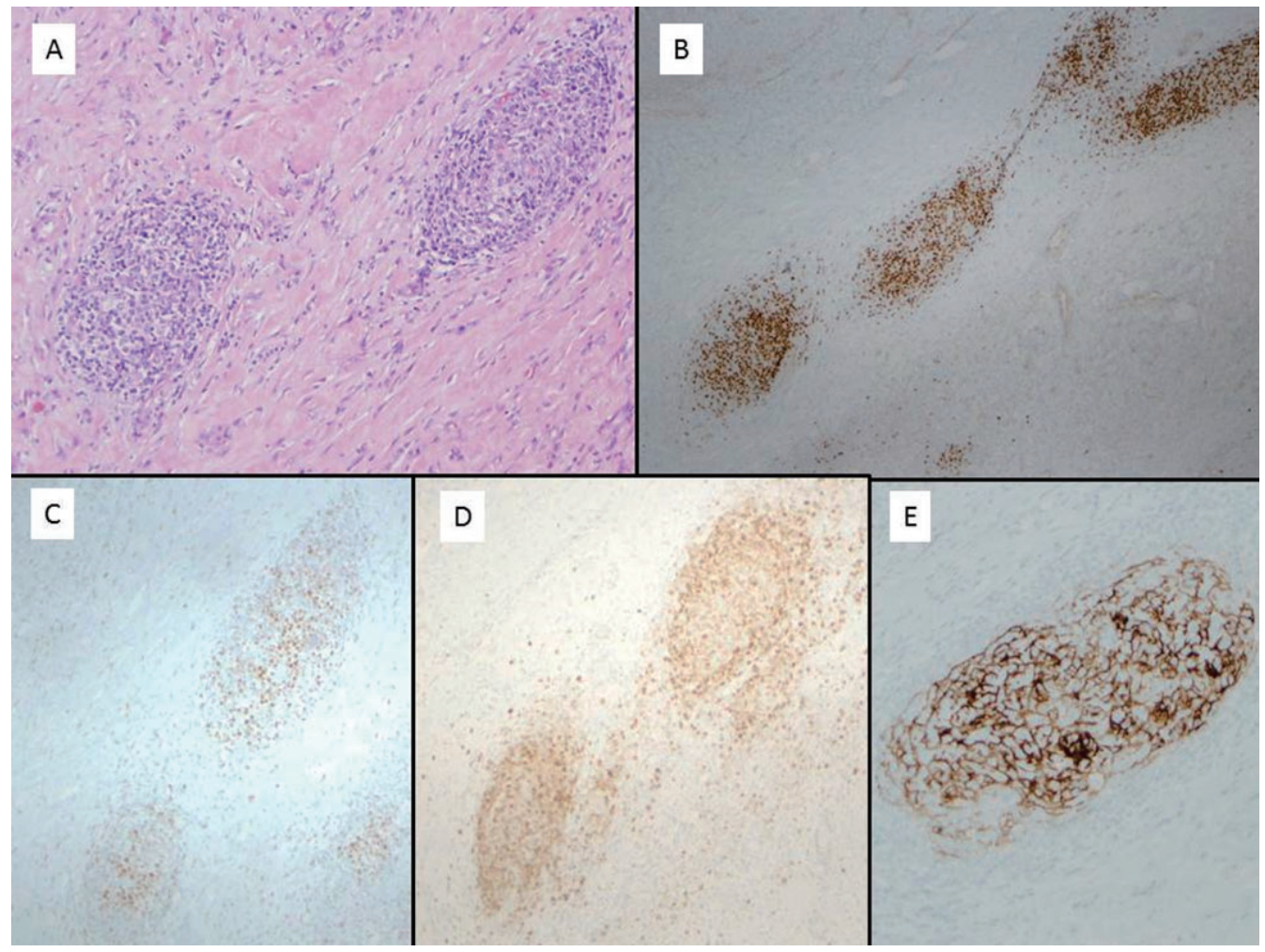

Figure 1. A: Histological features of isolated germinal centers noted in background suggestive of residual/recurrent follicular lymphoma $(\mathrm{H} \& \mathrm{E}, \times 100)$. Immunohistochemical features of the follicular lymphoma areas were focal positive for PAX-5 (B, ×40), BCL-2 (C, ×100), BCL-6 (D, ×100), and CD21 (E, × 200). 
The large neoplastic cells express S-100, CD68, CD4, MART-1 are negative in the large neoplastic cells. Ki-67 has CD163, Lysozyme, and CD45 (see Figure 2). BCL-6 is a variable proliferation index, with an average of $70 \%-80 \%$ variably/weakly positive in a subset of the large neoplastic cells. BCL-2 and CD43 are focal and rarely positive in the large neoplastic cells. Pancytokeratin, CD138, CD30, CD56, EMA, ALK, CD10, MUM-1, CD1a, CD34, CD117, and in the neoplastic cells. In-situ hybridization stains with appropriate positive and internal negative controls performed. Kappa/lambda ISH are negative for a restricted light chain population. EBER is negative.



Figure 2. Histopathological features of histiocytic sarcoma

A. Lower magnification shows a diffuse neoplastic infiltrate $(H \& E, \times 100)$; B. Higher magnification shows that the infiltrate is composed of large cells with vesicular chromatin and atypical, pleomorphic nuclei $(H \& E, \times 200)$; Immunohistological features of neoplastic cells were positive for S-100 (C), CD163 (D), CD68 (E), CD4 (F), (C-F; ×200); G. FISH analysis for t(14:18) with a dual color, dual fusion $I g H / B C L 2$ probe set showed fusion of the genes in yellow (white arrow) $(G, \times 200)$.

In summary, the large neoplastic cells express CD4, CD43 (focal staining), CD45, CD68, CD163, BCL-2 (focal staining), BCL-6, lysozyme and S-100. The morphologic and immunophenotypic findings support a diagnosis of HS with a small percentage $(<5 \%)$ of involvement by residual FL, grade I-II. Fluorescence in-situ hybridization (FISH) studies show translocation of $\mathrm{t}(14 ; 18)(\mathrm{q} 32 ; \mathrm{q} 21)$, a gene rearrangement involving 3q27 (BCL6) and a gain of 14q32 (IgH). A MYC translocation was not detected using a break-apart probe. The patient has a history of FL and diffuse large B cell lymphoma, which have shown $\mathrm{t}(14 ; 18)(\mathrm{q} 32 ; \mathrm{q} 21)$. BRAF
V600 testing by PCR was performed and showed no mutation was detected.

The current cytogenetic FISH studies show residual evidence of $\mathrm{t}(14 ; 18)(\mathrm{q} 32 ; \mathrm{q} 21)$ present in the large neoplastic cells. We were careful to pick a tissue block which showed no residual FL involvement by morphology and immunohistochemical stain. Our findings identify a clonal relationship between the patient's prior FL, the transformation to DLBCL and the current HS. The cytogenetic studies support the diagnosis of transdifferentiation from FL to HS which has been described 
in the literature by Feldman et al. ${ }^{[9]}$ This is a complex diagnosis and the case was sent out for expert consultation to the Mayo Clinic who agreed with the above interpretation.

\subsection{Clinical course}

Positron emission tomography (PET) scan after 2 cycles of RICE showed a suboptimal response; hence, he was started rituximab-cisplatin, cytarabine, cyclophosphamide, mesna, etoposide and dexamethasone (R-PAC-MED) combination chemotherapy. Following his second cycle of R-PAC-MED, PET scan showed increased size and activity of the right inguinal and external iliac nodes. Therefore, the patient started a new chemotherapy regimen including gemcitabine and Taxotere. If there is improvement, the clinical team is considering for the patient to undergo an autologous stem cell transplant.

\section{Discussion}

We report a case with FL, DLBCL and H/DC tumors, and provide evidence of the same underlying molecular oncogenetic alteration is present in all three neoplasms. There are no known environmental or hereditary genetic factors predisposing to the development of HS. HS can occur as an isolated disease or in the context of other hematologic neoplasms, such as FL, myelodysplasia, or acute lymphoblastic leukemia. ${ }^{[8]}$ When HS occurs in the context of another hematologic malignancy, the two entities are often clonally related..$^{[9,12]}$ FISH demonstrated the presence of $t(14 ; 18)(\mathrm{q} 32 ; \mathrm{q} 21)$ in our patient's FL, DLBCL and HS. Previous publication by Andrew L. Feldman, et al. evaluated 8 patients with both FL and $\mathrm{H} / \mathrm{DC}$ neoplasms using immunohistochemistry, FISH testing for $\mathrm{t}(14 ; 18)$, and polymerase chain reaction (PCR) sequencing of BCL2 and IGH rearrangements. FISH demonstrated the presence of $\mathrm{t}(14 ; 18)$ in 6 of $8 \mathrm{H} / \mathrm{DC}$ tumors. ${ }^{[9]}$ In the 2 cases in which FISH was not successfully performed, a clonal relationship between the FL and H/DC tumors was indicated by identical $B C L 2 / J H$ or clonal IGH gene rearrangements or both. ${ }^{[9]}$

Multiple case reports and rare small case series of H/DC neoplasms have been reported in patients with mature B-cell neoplasms. There have been isolated reports of $\mathrm{H} / \mathrm{DC}$ tumors occurring in patients with FL, CLL/SLL, and splenic marginal zone lymphoma. ${ }^{[6,10,11,13-15]}$ Rarely, FL involving the lymph node with co-existing DLBCL and HS in a bone marrow biopsy has been identified. ${ }^{[16]}$ Therefore, it is important to biopsy and evaluate lymph nodes and bone marrow lesions. ${ }^{[16]}$ The most common genetic abnormalities detected in patients with CLL/SLL and associated HS are $17 p$ abnormalities. ${ }^{[11]}$

Some studies have shown HS occurring in pediatric patients which is clonally related to the child's acute lymphoblastic leukemia (ALL). ${ }^{[7,17]} \mathrm{HS}$ has been associated with loss of p16 ${ }^{\mathrm{INK} 4 \mathrm{~A}}$ in murine models and human tumors. B-cell and T-cell ALL can have deletion of CDKN2A, which encodes p16 ${ }^{\text {INK4A }} \cdot{ }^{[17]}$ Study in mice have shown that down-regulation of PAX-5 allows previously determined B cells to reprogram to macrophages. ${ }^{[18]}$

There is no standard treatment regimen for patients with HS and patients should be encouraged to enroll in a clinical trial. Surgery, chemotherapy, and radiation have been tried with poor results. Allogeneic hematopoietic cell transplantation should be considered for patients who have relapsed or refractory disease that achieve a remission with salvage therapy. ${ }^{[19-22]}$

\section{CONFlicts OF InTEREST Disclosure}

The author declares no conflicts of interest.

\section{REFERENCES}

[1] Swerdlow SH, Campo E, Harris NL, et al. Histiocytic and dendritic neoplasms eds. World Health Organization Classification of Tumours of haematopoietic and lymphoid tissues. Lyon: IARC; 2008. 354p.

[2] Pileri SA, Grogan TM, Harris NL, et al. Tumours of histiocytes and accessory dendritic cells: an immunohistochemical approach to classification from the International Lymphoma Study Group based on 61 cases. Histopathology. 2002; 41: 1-29. PMid: 12121233. http://dx.doi.org/10.1046/j.1365-2559.2002.01418.x

[3] Chen W, Lau SK, Fong D, et al. High Frequency of clonal immunoglobulin receptor gene rearragnements in sporadic histiocytic/dendritic cell sarcomas. Am J Surg Pathol. 2009; 33: 863-73. PMid: 19145200. http://dx.doi.org/10.1097/PAS.0b013e3 1819287b8

[4] Baer MR, Krantz SB, Cousar JB, et al. Malignant histio- cytoses developing in patients with B-cell lymphomas. Report of two cases. Cancer. 1986; 57: 2175-84. PMid: 3486032. http://dx.doi.org/10.1002/1097-0142(198606 01) $57: 11<2175:$ :AID-CNCR2820571116>3.0.CO;2-R

[5] Wetzler M, Kurzrock R, Goodacre AM, et al. Transformation of chronic lymphocytic leukemia to lymphoma of true histiocytic type. Cancer. 1995; 76: 609-17. PMid: 8625154. http://dx.doi.org/10.1002/1097-0142(199508 15) $76: 4<609:$ : AID-CNCR2820760411>3.0.CO; $2-Y$

[6] Vasef MA, Zaatari GS, Chan WC, et al. Dendritic cell tumors associated with low-grade B-cell malignancies. Report of three cases. Am J Clin Pathol. 1995; 104: 696-701. PMid: 8526215. http://dx.doi.org/10.1093/ajcp/104.6.696

[7] Feldman AL, Minniti C, Santi M, et al. Histiocytic sarcoma after acute lymphoblastic leukaemia: a common clonal origin. Lancet 
Oncol. 2004; 5: 248-50. PMid: 15050956. http://dx.doi.org/1 $0.1016 / \mathrm{S} 1470-2045(04) 01428-7$

[8] Castro EC, Blazquez C, Boyd J, et al. Clinicopathologic features of histiocytic lesions following ALL, with a review of the literature. Pediatr Dev Pathol. 2010; 13: 225-37. PMid: 19642834. http://dx.doi.org/10.2350/09-03-0622-0A.1

[9] Feldman AL, Arber DA, Pittaluga S, et al. Clonally related follicular lymphomas and histiocytic/dendritic cell sarcomas: evidence for transdifferentiation of the folicular lymphoma clone. Blood. 2008; 111: 5433-9. PMid: 18272816. http://dx.doi.org/10.1182/b lood-2007-11-124792

[10] Wang E, Hutchinson CB, Huang Q, et al. Histiocytic sarcoma arising in indolent small B-cell lymphoma: report of two cases with molecular/genetic evidence suggestive of a 'transdifferentiation' during the clonal evolution. Leuk Lymphoma. 2010; 51: 802-12. PMid: 20331331. http://dx.doi.org/10.3109/10428191003 699845

[11] Shoa H, Xi L, Raffeld M, et al. Clonally related histiocytic/dendritic cell sarcoma and chronic lymphocytic leukemia/small lymphocyte lymphoma: a study of seven cases. Modern Pathology. 2011; 24: 1421-32. PMid: 21666687. http://dx.doi.org/10.1038/mod pathol.2011.102

[12] Reynaud D, Lefort N, Manie E, et al. In vitro identification of human pro-B cells that give rise to macrophages, natural killer cells, and T cells. Blood. 2003; 101: 4313-21. PMid: 12560235. http://dx.doi.org/10.1182/blood-2002-07-2085

[13] Cossu A, Deiana A, Lissia A, et al. Synchronous interdigitating dendritic cell sarcoma and B-cell small lymphocytic lymphoma in a lymph node. Arch Pathol Lab Med. 2006; 130: 544-7. PMid: 16594749 .

[14] Mehrotra S, Pan Z. Fine Needle Aspiration Cytology of Histiocytic Sarcoma with Dendritic Cell Differentiation: A Case of Transdifferentiation From Low-Grade Follicular Lymphoma. Diagn Cytopathol. 2015; 43: 659-63. PMid: 25993973. http://dx.doi.org/10.10 $02 / d c .23285$
[15] Stoecker MM, Wang E. Histiocytic/Dendritic Cell Transformation of B-Cell Neoplasms-Pathologic Evidence of Lineage Conversion in Differentiated Hematolymphoid Maliganancies. Arch Pathol Lab Med. 2013; 137: 865-70. PMid: 23721279. http://dx.doi.org /10.5858/arpa.2012-0104-RS

[16] Zhang D, McGuirk J, Ganguly S, et al. Histiocytic/dendritic cell sarcoma arising from follicular lymphoma involving the bone: a case report and review of literature. Int J Hematol. 2009; 89: 52932. PMid: 19343479. http://dx.doi.org/10.1007/s12185-0 09-0300-y

[17] Kumar R, Khan SP, Joshi DD, et al. Pediatric Histiocytic Sarcoma Clonally Related to Precursor B-Cell Acute Lymphoblastic Leukemia with Homozygous Deletion of CDKN2A Encoding p16 ${ }^{\mathrm{INK} 4 \mathrm{~A}}$. Pediatr Blood Cancer. 2011; 56: 307-10. PMid: 20973102. http://dx.doi.org/10.1002/pbc. 22810

[18] Xie H, Ye M, Feng R, et al. Stepwise reprogramming of B cells into macrophages. Cell. 2004; 117: 663-76. PMid: 15163413. http://dx.doi.org/10.1016/S0092-8674(04)00419-2

[19] Mainardi C, D'Amore ES, Pillon M, et al. A case of resistant pediatric histiocytic sarcoma successfully treated with chemo-radiotherapy and autologous peripheral blood stem cell transplant. Leuk Lymphoma. 2011; 52: 1367-71. PMid: 21425962. http://dx.doi.org/10.31 $09 / 10428194.2011 .565840$

[20] Gergis U, Dax H, Ritchie E, et al. Autologous hematopoietic stemcell transplantation in combination with thalidomide as treatment for histiocytic sarcoma: a case report and review of the literature. J Clin Oncol. 2011; 29: e251-3. PMid: 21220616. http: //dx.doi.org/10.1200/JC0.2010.32.6603

[21] Abidi MH, Tove I, Ibrahim RB, et al. Thalidomide for the treatment of histiocytic sarcoma after hematopoietic stem cell transplant. Am J Hematol. 2007; 82: 932-3. PMid: 17617785. http: //dx.doi.org/10.1002/ajh. 20913

[22] Shukla N, Kobos R, Renaud T, et al. Successful treatment of refractory metastatic histiocytic sarcoma with alemtuzumab. Cancer. 2012; 118: 3719-24. PMid: 22170006. http://dx.doi.org/10.1002 /cncr. 26712 